\title{
HUBUNGAN ASUPAN SERAT DAN CAIRAN DENGAN KEJADIAN KONSTIPASI PADA IBU PASCA MELAHIRKAN
}

\author{
Muawanah', Triska Susila Nindya² \\ ${ }^{1,2}$ Departement Gizi Kesehatan, Fakultas Kesehatan Masyarakat, Universitas Airlangga, Surabaya \\ Email: Muawanah-2014@fkm.unair.ac.id
}

\begin{abstract}
ABSTRAK
Konstipasi postpartum dengan gejala seperti rasa sakit atau rasa ketidaknyamanan, tegang, dan feses keras adalah kondisi umum yang mempengaruhi kejadian hemoroid dan nyeri di daerah episiotomi. Kejadian konstipasi sering berkaitan dengan kurangnya asupan serat dan asupan cairan. Penelitian ini bertujuan menganalisis hubungan asupan serat dan cairan dengan kejadian konstipasi pada ibu pasca melahirkan. Desain penelitian observasional dengan pendekatan cross sectional pada 33 ibu pasca melahirkan menggunakan metode systematic random sampling pada bulan April hingga Mei 2016. Analisis data dilakukan dengan uji chi-square. Hasil penelitian menunjukkan bahwa terdapat 97\% ibu pasca melahirkan memiliki asupan serat kurang dan hanya 3\% tergolong memiliki asupan serat baik. Terdapat 9,1\% ibu dengan asupan cairan tergolong kurang dan 90,9\% tergolong cukup. Terdapat 54,5\% ibu pasca melahirkan mengalami konstipasi, sedangkan 45,5\% tidak konstipasi. Berdasarkan uji chi-square didapatkan bahwa tidak ada hubungan yang signifikan antara asupan serat dan cairan dengan kejadian konstipasi ( $p>0,05)$. Kesimpulan penelitian ini yaitu tidak terdapat hubungan antara asupan serat dan asupan cairan dengan kejadian konstipasi pada ibu pasca melahirkan. Diperlukan edukasi kesehatan untuk mencegah terjadinya konstipasi pada ibu pasca melahirkan.
\end{abstract}

Kata kunci: asupan cairan, asupan serat, konstipasi, pasca melahirkan

\section{ABSTRACT}

Postpartum constipation with symptoms such as pain or discomfort, straining and hard stools is a common condition that affects the incidence of hemoroids and pain in the area of episiotomy. Constipation is associated with inadequate intake of fiber and fluid. This study aimed to analyze the relationship between intake of fiber, fluids and constipation in postpartum mother. The study design was observational with cross sectional approach on thirty three (33) post partum mothers using systemic random sampling method in April to May 2016. Data was analyzed by chi-square test. The result showed that $97 \%$ of postpartum mother had inadequate fiber intake and only $3 \%$ were adequate. There was 9.1\% postpartum mother with inadequate fluid intake and $90.9 \%$ were categorized as adequate. There was $54.5 \%$ of postpartum mother had constipation, while $45.5 \%$ not constipated. Based on chi-square test, there was no significant relationship between fiber intake, fluid intake and constipation $(p>0.05)$. The conclusion that there was no relationship in fiber intake, fluid intake with the incidence of constipation in postpartum mother. This requires provision of health education to prevent the occurance of constipation in postpartum mother.

Keywords: fluid intake, fiber intake, constipation, postpartum

\section{PENDAHULUAN}

Konstipasi adalah pergerakan feses yang lambat melewati usus besar dihubungkan dengan banyaknya jumlah feses yang kering dan keras yang terkumpul pada colon descenden yang disebabkan oleh absorbsi cairan yang berlebihan (Guyton dan Hall, 2006).

Konstipasi post partum dengan gejala seperti rasa sakit atau rasa ketidaknyamanan, tegang, dan feses keras adalah kondisi umum yang mempengaruhi kejadian hemoroid dan nyeri di daerah episiotomi. Hal ini akibat pengaruh hormon kehamilan dan penggunaan zat besi sebagai suplemen sehingga dapat meningkatkan resiko konstipasi pada ibu post partum (Turawa et al., 2015). Konstipasi mempengaruhi sekitar 20-25\% dari populasi, dapat terjadi pada semua umur dan didominasi oleh perempuan dengan rasio kejadian antara perempuan dan laki-laki sebesar 2:1 (Kassolik, et al., 2015).

Menurut Kusharto (2006), serat mampu mengatasi konstipasi karena serat di metabolisme 
oleh bakteri yang berada dan melalui saluran cerna. Pengaruh nyata yang telah dibuktikan adalah bertambahnya volume feses, melunakkan konsistensi feses, memperpendek waktu transit di usus, dan memproduksi flatus.

Air merupakan komponen utama dalam tubuh manusia. Sekitar $80 \%$ dari kebutuhan individu merupakan kontribusi cairan termasuk air, dan sisanya diperoleh dari makanan. Kebutuhan cairan setiap individu dipengaruhi oleh berbagai faktor seperti usia, jenis kelamin, tingkat aktivitas, faktor lingkungan, dan status gizi (Popkin, et al., 2006). Salah satu fungsi air sebagai penghancur makanan (Potter dan Perry, 2006).

Menurut Bradley, et al. (2007), dari 103 wanita hamil terdapat $24 \%$ wanita hamil trimester pertama, 26\% wanita hamil trimester kedua dan $26 \%$ wanita hamil trimester ketiga mengalami konstipasi, sedangkan terdapat $24 \%$ wanita mengalami konstipasi selama 3 bulan pertama setelah melahirkan. Penelitian ini bertujuan menganalisis hubungan asupan serat dan cairan dengan kejadian konstipasi pada ibu pasca melahirkan.

\section{METODE}

Penelitian ini dilakukan di wilayah kerja Puskesmas Jagir Surabaya pada bulan April sampai Mei 2016. Jenis penelitian ini bersifat observasional dengan pendekatan cross sectional. Sampel pada penelitian ini yaitu ibu pasca melahirkan yang mengikuti penelitian POGI (Persatuan Obstetri dan Ginekologi Indonesia) yaitu sebanyak 33 responden. Teknik pengambilan sampel dengan systemic random sampling.

Penelitian ini telah dinyatakan lolos uji etik oleh Komisi Etik Penelitian kesehatan Fakultas Kesehatan Masyarakat Universitas Airlangga dengan No: 128-KEPK. Data yang digunakan dalam penelitian ini adalah data primer. Data primer berupa data asupan serat, asupan cairan selama 3 hari dan skrining gejala konstipasi ibu pasca melahirkan yang diperoleh dari wawancara responden dan kuesioner. Data asupan serat diperoleh dengan menggunakan kuesioner food recall $3 \times 24$ jam. Data asupan serat dikelompokkan menjadi dua kategori yaitu baik
( $\geq 14$ gram) atau kurang $(<14$ gram) (Hardinsyah, et al., 2010).

Data asupan cairan diperoleh dengan menggunakan formulir catatan minum selama 3 hari (3D-fluid diary). Data konsumsi cairan dikelompokkan menjadi dua kategori yaitu kurang $(<65 \%$ AKG) dan cukup ( $\geq 65 \%$ AKG) menurut Hardinsyah, et al. (2011).

Data gejala konstipasi menggunakan kuesioner meliputi frekuensi defekasi, keluhan mengejan, dan tipe feses berdasarkan The Bristole Stool Form Scale (Purwaka, et al., 2014). Konstipasi ditegakkan selama 7 hari yaitu ditemukan 2 keluhan antara lain frekuensi defekasi kurang dari $3 \mathrm{kali} /$ minggu, adanya keluhan mengejan, dan feses yang termasuk kategori tipe 1,2,3 pada Bristole Stool Form Scale.

Analisis data pada penelitian ini yaitu analisis univariat pada umur, pendidikan, pekerjaan. Analisis hubungan asupan serat, cairan dengan kejadian konstipasi pada ibu pasca melahirkan dilakukan dengan melakukan uji chi-square $(\alpha=0,05)$.

\section{HASIL DAN PEMBAHASAN}

\section{Karakteristik Responden}

Subjek dalam penelitian ini berjumlah $33 \mathrm{ibu}$ pasca melahirkan. Tabel 1 menunjukkan bahwa karakteristik berdasarkan umur responden $100 \%$ berada pada kelompok umur 20-35 tahun. Umur sangat berpengaruh terhadap kehamilan maupun persalinan. Pada penelitian ini umur responden termasuk dalam umur 20-35 tahun yaitu umur masa reproduksi sehat dan tergolong risiko rendah terjadinya komplikasi dalam kehamilan maupun persalinan (Gunawan, 2010).

Mayoritas pendidikan responden yaitu SMA sebanyak 19 responden $(57,6 \%)$ dan pendidikan tertinggi adalah Akademi/PT sebanyak 5 responden $(15,1 \%)$. Tingkat pendidikan dapat berpengaruh pada pola berfikir seseorang. Pada umumnya, seseorang yang memiliki tingkat pendidikan tinggi maka semakin baik pula pengetahuannya sehingga lebih mudah untuk melakukan komunikasi dan menyerap informasi termasuk informasi tentang kesehatan khususnya pengetahuan tentang gizi 
Tabel 1. Distribusi Karakteristik Responden

\begin{tabular}{lrr}
\hline \multicolumn{1}{c}{ Karakteristik } & $\begin{array}{c}\text { Jumlah } \\
\text { (n) }\end{array}$ & $\begin{array}{c}\text { Presentase } \\
(\%)\end{array}$ \\
\hline Umur & 0 & 0 \\
$<20$ tahun & & \\
$20-35$ tahun & 33 & 100 \\
$>35$ tahun & 0 & 0 \\
Pendidikan & & \\
$\quad$ SD-SMP & 9 & 27,3 \\
SMA & 19 & 57,6 \\
AKADEMI/PT & 5 & 15,1 \\
Pekerjaan & & \\
Karyawati & 1 & 3,0 \\
Pedagang & 1 & 3,0 \\
IRT & 26 & 78,8 \\
$\quad$ Wiraswasta & 5 & 15,2 \\
\hline
\end{tabular}

sehingga menambah pengetahuan dan mampu mengaplikasikannya dalam menjalankan kehidupan sehari-hari (Kuswardinah, 2007).

Pekerjaan responden terbanyak adalah IRT sebanyak $26(78,8 \%)$, di mana aktivitas harian sebagian besar dihabiskan di rumah. Pada ibu rumah tangga, kurangnya aktivitas fisik sangat berpengaruh terhadap kesehatannya karena cenderung kurang gerak dan tidak punya waktu luang untuk melakukan olah raga.

\section{Asupan Serat, Cairan dan Kejadian Konstipasi}

Asupan serat adalah jumlah makanan (serat) yang dikonsumsi oleh responden berdasarkan food recall $3 \times 24$ jam. Asupan cairan adalah rerata jumlah cairan yang diminum oleh responden berdasarkan catatan minum selama 3 hari (3D-fluid diary). Konstipasi adalah gangguan pencernaan berupa terhambatnya pengeluaran sisa-sisa makanan, pengukurannya berdasarkan data skrinning frekuensi defekasi, keluhan mengejan, dan tipe feses selama 1 minggu berdasarkan wawancara dan kuesioner.

Berdasarkan tabel 2 rata-rata asupan serat ibu pasca melahirkan masih tergolong kurang hanya memenuhi sekitar $40 \%$ dari angka kecukupan yang dianjurkan. Berdasarkan hasil riset Puslitbang Gizi Depkes RI tahun 2001, rata-rata konsumsi serat penduduk Indonesia adalah 10,5 gram setiap hari. Angka ini menunjukkan bahwa penduduk Indonesia baru memenuhi kebutuhan seratnya
Tabel 2. Rata-rata Asupan Serat, Cairan Pada Ibu Pasca Melahirkan

\begin{tabular}{lc}
\hline & Mean \pm SD \\
\cline { 2 - 2 } & Ibu postpartum \\
\hline Serat $(\mathrm{gram})$ & $7.40 \pm 2.58$ \\
Cairan $(\mathrm{ml})$ & $2500.81 \pm 997.1$ \\
\hline
\end{tabular}

sekitar $1 / 3$ dari kebutuhan ideal rata-rata 30 gram setiap hari.

Berdasarkan tabel 2, rata-rata asupan ibu pasca melahirkan telah memenuhi 94\% rekomendasi yang dianjurkan. Hal ini sesuai dengan penelitian yang dilakukan Paan, et al. (2012) di Amerika menunjukkan bahwa konsumsi air putih kepada kelompok wanita usia 25-42 tahun sebesar $>2$ liter per hari.

Tabel 3 menunjukkan konstipasi terjadi pada ibu pasca melahirkan sebanyak $54,5 \%$. Hal ini sejalan dengan penelitian Cheng dan Qing (2008) yang menyatakan bahwa pada ibu pasca melahirkan dapat mengalami kondisi kesehatan fisik tertentu diantaranya kejadian konstipasi dan hemoroid dalam 2 tahun postpartum.

\section{Analisis Hubungan Asupan Serat, Cairan dengan Kejadian Konstipasi}

Pada tabel 3 menunjukkan hasil penilaian sebagian besar ibu pasca melahirkan memiliki asupan serat kurang yaitu 32 responden (97\%). Hasil uji chi-square antara asupan serat dan konstipasi menunjukkan bahwa tidak ada hubungan yang signifikan antara kedua variabel tersebut $(\mathrm{p}>0,05)$.

Menurut Uliyah dan Ahmad (2008), makanan yang memiliki kandungan serat tinggi dapat membantu proses percepatan defekasi namun jumlah serat dan jenis serat juga sangat berperan. Serat dapat mencegah dan mengurangi konstipasi karena dapat menyerap air ketika melewati saluran pencernaan sehingga meningkatkan ukuran feses, namun jika asupan air kurang, serat akan menyebabkan konstipasi dan menyebabkan gangguan pada usus besar.

Salah satu faktor yang berpengaruh terhadap kesehatan ibu pasca melahirkan ialah asupan zat gizi. Diet dan jenis makanan yang dikonsumsi dapat mempengaruhi proses defekasi. Analisis antara asupan cairan dan konstipasi menggunakan 
Tabel 3. Analisis Hubungan Asupan Serat, Cairan dan Konstipasi pada Ibu Pasca Melahirkan

\begin{tabular}{|c|c|c|c|c|c|}
\hline & \multicolumn{4}{|c|}{ Konstipasi } & \multirow{3}{*}{ Pvalue } \\
\hline & \multicolumn{2}{|c|}{ Ya } & \multicolumn{2}{|c|}{ Tidak } & \\
\hline & $\mathbf{n}$ & $\%$ & n & $\%$ & \\
\hline \multicolumn{6}{|c|}{ Asupan Serat } \\
\hline Kurang & 9 & 27,3 & 23 & 69,7 & 0,534 \\
\hline Baik & 0 & 0 & 1 & 3,0 & \\
\hline \multicolumn{6}{|c|}{ Asupan Cairan } \\
\hline Kurang & 1 & 3,0 & 2 & 6,1 & \multirow{2}{*}{0,805} \\
\hline Cukup & 8 & 24,2 & 22 & 66,7 & \\
\hline
\end{tabular}

uji chi-square menunjukkan bahwa tidak terdapat hubungan yang signifikan antara asupan cairan dengan kejadian konstipasi $(\mathrm{p}>0,05)$. Pada penelitian ini di dapatkan hasil sekitar $90 \%$ asupan cairan ibu pasca melahirkan dalam kategori cukup, namun kejadian konstipasi tetap terjadi. Hal ini bisa disebabkan karena pada wanita 3 bulan pasca melahirkan masih terjadi peningkatan kadar hormon progesteron yang dapat menyebabkan sistem pencernaan melambat sehingga dapat menimbulkan konstipasi. Dengan mengonsumsi makanan berserat dan minum yang cukup serta aktifitas secara teratur akan membantu mencegah konstipasi.

Salah satu faktor yang mempengaruhi proses defekasi adalah asupan air. Air memiliki berbagai fungsi antara lain sebagai media eliminasi sisa metabolisme. Tubuh menghasilkan berbagai sisa metabolisme termasuk toksin. Sisa metabolisme tubuh dikeluarkan melalui saluran kemih, saluran nafas, kulit dan saluran cerna dengan media air (Kant dan Graubard, 2010).

Pada penelitian ini didapatkan hasil tidak ada hubungan antara asupan serat dan cairan dengan kejadian konstipasi pada ibu pasca melahirkan. Hasil ini tidak sejalan dengan penelitian Sari (2011) yang menyebutkan bahwa ada hubungan antara pola makan berserat dengan kejadian konstipasi. Asupan makanan seseorang sangat dipengaruhi oleh banyak faktor antara lain tingkat pendidikan dan pengetahuan gizi, ketersediaan waktu yang dimiliki ibu, pekerjaan dan pendapatan keluarga serta kebiasaan individu dan lingkungan dalam mengonsumsi makanan (Notoatmodjo, 2010).

Hasil penelitian menyatakan mengubah asupan makanan dengan diet tinggi serat dikombinasikan dengan minum banyak air dapat mengoptimalkan waktu transit sisa-sisa pencernaan dalam saluran pencernaan secara normal sehingga mencegah dan mengurangi konstipasi pada ibu pasca melahirkan (Trottier, et al. , 2012).

\section{KESIMPULAN DAN SARAN}

Berdasarkan hasil penelitian dan analisis dapat disimpulkan bahwa tidak ada hubungan asupan serat, cairan dengan kejadian konstipasi pada ibu pasca melahirkan. Asupan serat bagi ibu pasca melahirkan masih jauh dari angka kecukupan yang dianjurkan. Selain asupan serat dan asupan cairan masih banyak faktor yang berpengaruh terhadap kejadian konstipasi seperti hormon, perubahan anatomi dan asupan zat gizi.

Peningkatan edukasi kepada ibu pasca melahirkan untuk meningkatkan status kesehatannya yang berkaitan dengan pencegahan terjadinya konstipasi dan asupan zat gizi yang seimbang perlu dilakukan.

\section{DAFTAR PUSTAKA}

Bradley, C.S., Kennedy, C.M., Turcea, A.M., Rao, S.S., Nygaard, I.E. (2007). Constipation prevalence and risk factors in pregnancy. $J \mathrm{Gen}$ Intern Med, 64, 195-198.

Cheng, C-Y., and Qing, L. (2008). Integrative Review of Reseach on General Health Status and Prevalence of Common Physical Health Conditions of Women After Child Birth. Women's Health Issues, 18, 267-280. doi:10.1016/j. whi.2008.02.004

Departemen Kesehatan RI. (2001). Epidemiologi Konsumsi Serat di Indonesia. Jakarta: Puslitbang Gizi Departemen Kesehatan RI.

Gunawan, S. (2010). Reproduksi Kehamilan dan Persalinan. Yogyakarta: CV Graha.

Guyton, A.C and Hall, J.E., (2006). Constipation, Medical Physiology: Physiology of Gastrointestinal Disorder. Elsieveir Publisher: 11th Ed, 819-825.

Hardinsyah, Hadi, R., Victor, N. (2010). Angka Kecukupan Energi, Protein, Lemak dan Karbohidrat. Prosiding Widyakarya Nasional Pangan dan Gizi VIII. Jakarta.

Hardinsyah, Siregar, P., Santoso, B.I., Pardede, S.O. (2011). Air Bagi Kesehatan. Jakarta: Centra Communications. 
Kant, A.K., Graubard, B.I. (2010). Contributors of Water Intake in US Children and Adolescents: Assosiations with Dietary and Meal Characterisstics-National Health and nutrition Examination Survey 2005-2006. Am J Clin Nutr, 92, 887-896.

Kassolik, K., Waldemar, A., Iwona, W., Marcin, B., Kamila, V., Ewa, J-K., Barbara, N., Donata, K. (2015). The Effectiveness of Massage Based on The Tensegrity Principle Compared with Classical Abdominal Massage Performed on Pattient with Constipation. Archives of Gerontology and Geriatrics, 61, 202-211.

Kusharto, C.M. (2006). Serat Makanan dan Peranannya bagi Kesehatan. Jurnal Gizi dan Pangan, 1(2), 45-54.

Kuswardinah, A. (2007). Ilmu Kesejahteraan Keluarga. Semarang: UNNES Press.

Notoatmojo, S. (2010). Ilmu Perilaku Kesehatan. Jakarta: Rineka Cipta.

Paan, A., Vasanti, S.M., Mathias, B.S., Joann, E.M., Water, C.W., Frank, B.H. (2012). Plan Water Intake and Risk of Type 2 Diabetes In Young and Middle aged Women. Am J Clin Nutr, 95, 1454-1460.

Persatuan Obstetri dan Ginekologi Indonesia. (2013). Konsensus Nasional Kecukupan Asupan Air pada Ibu Hamil, Melahirkan dan Menyusui. Medan.
Potter, P.A and Perry, A.G. (2006). Buku Ajar Fundamental: Konsep, Proses dan Praktik. Jakarta: EGC.

Popkin, B.M., Lawrence, E.A., George, M.B., Benjamin, C., Balz, F., Walter, C.W. (2006). A New Proposed Guidance System for Beverage Consumption in The United State. $\mathrm{Am}$ J Clin Nutr, 83, 529-542.

Purwaka, B.T., Prasetya, B., Fitriana, D. (2014). Hubungan Antara Pola Nutrisi Serat dan asupan Cairan dengan Kejadian Konstipasi pada Ibu Hamil di Puskesmas Jagir Surabaya. Laporan Penelitian. Departemen/SMF Obstetri dan Ginekologi RSUD Dr. Soetomo. Surabaya.

Sari, A.E. (2011). Hubungan Pola Makan Berserat dengan Kejadian Konstipasi di Rumah Sakit haji Adam Malik. (Skripsi, Universitas Sumatera Utara, Medan)

Turawa, E.B., Musekiwa, A., Rohwer, A.C. (2015). Interventions For Preventing Post Partum Constipation. PubMed Cochrane Database Syst Rev, 18(9). doi: 10.1002/14651858.CD011625. pub2

Trottier, M., Erebara, A. and Bozzo, P. (2012). Treating Constipation During Pregnancy. Can Fam Physician, 58(8), 836-838.

Uliyah, M., and Ahmad, H. (2008). Keterampilan Dasar Praktik Klinik untuk Kebidanan. Jakarta: Salemba Medika. 